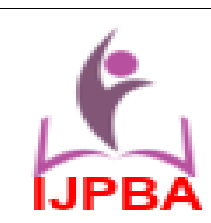

Contents lists available at www.ijpba.in

International Journal of Pharmaceutical and Biological Science Archive

NLM (National Library of Medicine ID: 101738825)

Index Copernicus Value 2019: 71.05

Volume 9 Issue 2; March-April; 2021; Page No. 01-06

\title{
PHYTOCHEMICAL EVALUATION OF INDIGOFERA ASTRAGALINA
}

B. Tailor* and Y. Singh

Department of Pharmacognosy Sunrise University Alwar, Rajasthan

Conflicts of Interest: Nil

Corresponding author: B. Tailor

DOI: https://doi.org/10.32553/ijpba.v9i2.182

\section{ABSTRACT}

The word diabetes is Greek for a draw off, referring to the ejection of a more quantity of urine; and mellitus is Latin used for sugar. Consequently diabetes mellitus means the passage of huge amounts of sweet urine. This is derived from the information that excess glucose in the blood spills over into the urine, absorbing fluids with it. Based on the exhaustive literature survey, the objective of the present work focussed on the search of herb to be proved as more suitable among the reported herbs/ herbal preparations/claimed herbs, towards the control of blood glucose level in hyperglycemic condition. In the present investigation herbs; Indigofera astragalina were considered based on their literature information. In general, there is very little biological knowledge on the specific modes of action in the treatment of diabetes, but most of the plants have been found to contain substances like phenols, glycosides, alkaloids, terpenoids, flavonoids etc., that are normally concerned as having antidiabetic effect.

Keywords: Antidiabetic activity, alkaloids, Flavonoid, Phenol and Indigofera Astragalina.

\section{INTRODUCTION}

Diabetes is a costly disease for the health care sector, at communal and at individual level. Expenditure of diabetes care is extremely high. The cost of concern increases a lot of folds when complications occur or when access to hospital, operation or insulin treatment is needed. A study by the authors has shown that the yearly median expenses by patients on diabetes care are Rs 10,000 in city and Rs 6,300 in rustic areas [1]. A low-income person spends nearly $25-35 \%$ of their yearly income on diabetes concern. Due to the high financial burden on the patients as well as their families, people are likely to neglect health care causing severe morbidities and early death.

Insulin biosynthesis occurs in rough endoplasmic reticulum from a single-chain precursor, preproinsulin, with a molecular weight of 11,500 with containing 109 amino acids. This molecule consists of proinsulin in addition a hydrophobic extension of 23 amino acids (preregion) on the $\mathrm{N}$ terminus of proinsulin. Proinsulin is claved to form equimolar amounts of C-peptide and insulin. Insulin is a protein composed of fifty one amino acids in two chains ( $A$ and $B$ chains), linked by two disulfide bonds. Insulin is synthesized and accumulated in the $\beta$-cells of the islets of langerhans, which are situated in the pancreas. The normal pancreas contains $200 \mathrm{U}$ insulin, and a basal amount of insulin is secreted always at a rate of roughly 0.5 to $1.0 \mathrm{U} / \mathrm{h}$.

Diabetes mellitus emerges in two diversities, everyone with its individual cause: diabetes mellitus type I (previously known as juvenile onset diabetes), caused by lack of the pancreatic hormone insulin (whose principal function is to encourage the entry of glucose into cells); and diabetes mellitus type II (previously known as maturity onset diabetes), in which insulin is accessible but cannot be appropriately utilized (The expert committee on the diagnosis and classification of diabetes 
mellitus, 2002). The third group consists of other less common types of diabetes that are caused or associated with certain specific conditions and/or syndromes. The very last group comprises diabetes diagnosed during pregnancy, called gestational diabetes (GDM) [3]. Long before the birth of orthodox Western medicine, medicinal herbs were applied to treat a wide range of disease categories [3]. Due to emphasis on scientism and other complicated reasons, Western medicine now prevails over "traditional" forms of medicine including herbal medicine systems. The use of a medicinal herb, alone or in combination with other herbs, can be thought of as a type of combination therapy because of the complexity of the phytochemicals and bioactivities in the plant. Thus, a single antidiabetic herb [4] with thousands of phytochemicals may have multiple benefits by targeting several metabolic pathways and essentially "killing several birds with one stone."

\section{MATERIALS AND METHODS}

\section{Collection and Preparation of Plant Extract:}

Drug discovery from medicinal plants has evolved to include numerous fields of inquiry and various methods of analysis. The process typically begins with a botanist, ethno botanist, ethnopharmacologist, or plant ecologist [5] who identifies the plant of interest. Collection may involve species with known biological activity for which active compound(s) have not been isolated (e.g., traditionally used herbal remedies) or may involve taxon collected randomly for a large screening program. On the basis of intensive literature survey; $I$. astragalina was selected for present study [6].

\section{Ash Values:}

The residues remaining after incineration is the ash content of the fruits powder. Ash values are helpful in determining the quality and purity of crude drug, especially in the powdered form [7]. It usually represents the inorganic salts naturally occurring in the drug and adhering to it, but it may also include inorganic matter added for the purpose of adulteration.

\section{Determination of total ash value:}

Accurately weighed about $3 \mathrm{gm}$ of air dried powdered drug was taken in a tared silica crucible and incinerated by gradually increasing the temperature to make it dull red hot until free from carbon. Cooled and weighed, repeated for constant value. Then the percentage of total ash was calculated with reference to the air dried drug [8].

\section{Extraction and fractionation:}

The extraction yield of the extracts from plant species is vastly depends on the solvent polarity, which find out both qualitatively and quantitatively the extracted compounds. Ethanol and water are the commonly used solvent for the extraction because of their low toxicity and high extraction yield with the advantage of modulating the polarity of the solvent by using mixtures at different ratios [911] The plant materials ( $1 \mathrm{~kg}$ ) were initially defatted with petroleum ether and then extracted with alcohol and water using a Soxhlet apparatus. The yield of the plant extracts ethanol (95\%) and aqueous measured about $20 \mathrm{~g}$ each after evaporating the solvent using water bath. The standard extracts obtained from Indigofera astragalin were then stored in a refrigerator at $4^{\circ} \mathrm{C}$ [12].

\section{Phytochemical screening}

\section{Qualitative examination of phytoconstituents:}

Extract has been tested for phytoconstituents present in extract as per procedure, 
Preliminary phytochemical study of the $I$. astragalin extracts/fractions [13]. The medicinal plants are useful for healing as well as for curing of human diseases because of the presence of phytochemical constituents. The preliminary phytochemical screening was carried out to assess the qualitative chemical composition of crude extracts and fractions from 1 . astragalin by using precipitation and coloration reaction to identify the major natural chemical groups [14-18] General reactions in this analysis revealed the presence or absence of these compounds in the crude extracts and fractions tested.

\section{CONCLUSION}

The present investigations concluded that the

ethanolic and aqueous extracts of aerial parts of I. astragalin endowed with potential antidiabetic activity which could be attributed by their possible multiple effects on both pancreatic and extra-pancreatic site by influencing either the metabolism and/or absorption of glucose, which in turn also influence the lipid metabolism. Conversely the extracts and fractions of both plants exert very good potentials to scavenge toxic free radicals along with the inhibition of the liver lipid peroxidation products and activation of the enzymatic antioxidant defense mechanism in diabetic rats that might be due to the presence of high levels of sterols, phenolics, alkaloids and flavonoids, which may be responsible for the supporting properties of the extracts and fractions for their hypoglycaemic and antidiabetic activity. Stigmasterol, a plant sterol isolated from chloroform fraction of $I$. astragalin.

Table-1: Phytochemical screening of extracts and fractions of $I$. astragalin

\begin{tabular}{|c|c|c|c|c|c|}
\hline \multirow[t]{2}{*}{ Chemical constituents } & \multirow[t]{2}{*}{ Chemical Test } & \multicolumn{4}{|c|}{ Extracts/Fractions } \\
\hline & & $\begin{array}{l}\text { Ethanol } \\
\text { extract }\end{array}$ & $\begin{array}{l}\text { Aqueous } \\
\text { extracts }\end{array}$ & $\begin{array}{l}\text { Chloroform } \\
\text { fraction }\end{array}$ & $\begin{array}{l}\text { Aqueous } \\
\text { fraction }\end{array}$ \\
\hline \multirow[t]{4}{*}{ Alkaloids } & Mayer's & + & + & + & + \\
\hline & Dragendorff's & + & + & + & + \\
\hline & Wagner's & - & - & - & - \\
\hline & Hager's & + & + & + & + \\
\hline \multirow[t]{2}{*}{ saponin } & Foam & - & + & - & - \\
\hline & Haemolytic & - & - & - & - \\
\hline \multirow{3}{*}{$\begin{array}{l}\text { Phenolic compounds } \\
\text { and Tannins }\end{array}$} & Ferric Chloride & + & + & + & + \\
\hline & Gelatin & - & - & - & \\
\hline & Lead acetate test & + & + & + & + \\
\hline \multirow[t]{3}{*}{ Proteins } & Million's & + & - & + & - \\
\hline & Biuret & + & + & + & - \\
\hline & Xanthoprotein & - & - & - & - \\
\hline
\end{tabular}




\begin{tabular}{|c|c|c|c|c|c|}
\hline \multirow[t]{3}{*}{ Flavonoids } & Ferric Chloride & + & + & - & + \\
\hline & Shinoda & - & - & - & - \\
\hline & Lead Acetate & + & + & + & + \\
\hline \multirow[t]{4}{*}{ Glycoside } & Baljet's & - & - & - & - \\
\hline & Legal's & - & - & - & - \\
\hline & Borntrager's & - & - & - & - \\
\hline & Killer killani & - & - & - & - \\
\hline Fixed oil & Spot & - & - & - & - \\
\hline \multirow[t]{5}{*}{ Carbohydrate } & Molisch's & - & - & - & - \\
\hline & Fehling's & + & + & + & + \\
\hline & Benedict's & - & - & - & - \\
\hline & Barfoed's & + & + & + & + \\
\hline & Cobalt-chloride & - & - & - & \\
\hline Gums and mucilage & Swelling Index & - & - & - & - \\
\hline \multirow[t]{3}{*}{ Amino Acids } & Ninhydrin & - & - & - & - \\
\hline & Tyrosin & - & - & - & - \\
\hline & Tryptophan & - & - & - & - \\
\hline \multirow[t]{2}{*}{ Sterols and triterpenes } & $\begin{array}{l}\text { Liebermann- } \\
\text { Burchard's }\end{array}$ & + & + & + & - \\
\hline & Salkowski's & + & - & + & - \\
\hline
\end{tabular}

Key $(+)=$ Presence, $(-)=$ Absent

\section{ACKNOWLEDGEMENT}

The authors are grateful to acknowledge the PG \& Research department of Pharmacognosy, Sunrise University alwar for providing necessary facilities during the study.

\section{REFERENCES}

1. Abdin, M.Z., Israr, M., Rehman, R.U., economic plants of Nupeland. Jube Jain, S.K., 2003. Artemisinin, a novel Evans, 2003.

antimalarial drug: biochemical and molecular approaches for enhanced production. Planta Medica 69(4), 289299.

2. Abdullahi, M., Muhammed, G., Abdulkadir, N.U., 2003. Medicinal and

3. Abubacker, M.N., Ramanathan, R., 2012. Antibacterial Activities of Indigofera astragalin (Papavaraceae) Leaf Extract on Pathogenic Bacterial Strains. Drug Invention Today 4(6), 385387. 
4. pathophysiology. Journal of the American Medical Association 301, 2129-2140.

5. Chan, S.J., Keim, P., Steiner, D.F., 1976. Cell-free synthesis of rat preproinsulins: characterization and partial amino acid sequence determination. Proceeding of the National Academic Sciences USA 73, 1964-1968.

6. Kaur R., Afzal M., Kazmi I., 2012. Polypharmacy (herbal and synthetic drug combination): a novel approach in the treatment of type- 2 diabetes and its complications in rats. Journal of Natural Medicines 67(3), 662-71.

7. Kaur, C., Binoy, G., Deepa, N., Balraj, S., Kapoor, H. C., 2004. Antioxidant Status of Fresh and Processed Tomato. Journal of Food Science and Technology 41, 479-480.

8. Kaur, K., Bedi, G., Kaur, M., Anil, V., Kaur, I., 2008. Lipid Peroxidation and the Levels of Antioxidant Enzymes in Coronary Artery Disease. Indian Journal of Clinical Biochemistry 23(1), 33-37.

9. Pickett, S.D., McLay, I.M., Clark, D.E, 2000. Enhancing the hit-to-lead properties of lead optimization libraries. Journal of Chemical Information and Modeling 40, 263-272.
10. Pillai, M.K., 2006. Could You Be A Diabetic? Reader's Digest, January, 137141.

11. Pingale, S.S., 2013. Toxicity Study for Indigofera astragalin World Journal of Pharmaceutical Sciences 1(4): 151155.

12. Pingale, S.S., Pokharkar, R.D., Pingale, M.S., 2008. Effect of Indigofera astragalin root bark on evaluation of Hepatoprotective action in rats. Pharmacologyonline 1, 13-19.

13. Singh, S., Singh, A., Jaiswal, J., Singh, T.D., Singh, V.P., Pandey, V.B., Tiwari, A., Singh, U.P., 2010a. Antifungal activity of the mixture of quaternary alkaloids isolated from Argemone mexicana against some phytopathogenic fungi. Archives of Phytopathology and Plant Protection 43, 769-774.

14. Singh, S., Singh, D.K., 1999. Molluscicidal property of seeds of Argemone mexicana. Chemosphere 38(14), 3319-3328

15. Zak, A., Zeman, M., Vitkova, D., Hrabak, P., Tvrzicka, E., 1990. Beta-sitosterol in the treatment of hypercholesterolemia. Journal of Czech Physicians 129, 13201323.

16. Zarzuelo, A., Risco, S., Gamez, M.J., Jimenez, J., Cámara, M., Martinez, M.A., 
1990. Hypoglycemic action of Salvia lavandulifolia Vahl. spp. oxyodon: a contribution to studies on the mechanism of action. Life Sciences 47, 909-915.

17. Zhang, H., Zdolsek, J.M., Brunk, U.T., 1992. Alloxan cytotoxicity involves lysosomal damage. Acta Pathologica
Microbiologica Et Immunologica Scandinavica 100, 309-316.

18. Zhang, L.H., Xiao, P.G., 1993. Recent advances in Studies of Antihyperlipaemic and Antihyperglycemic compounds from Chinese traditional and herbal medicines. Phytotherapy Research 7, 217-226. 